\section{For Reference}

Not to be taken from this room

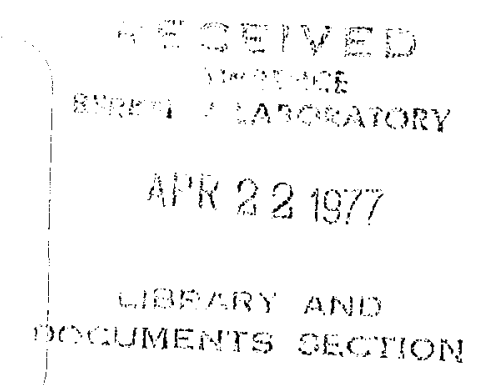

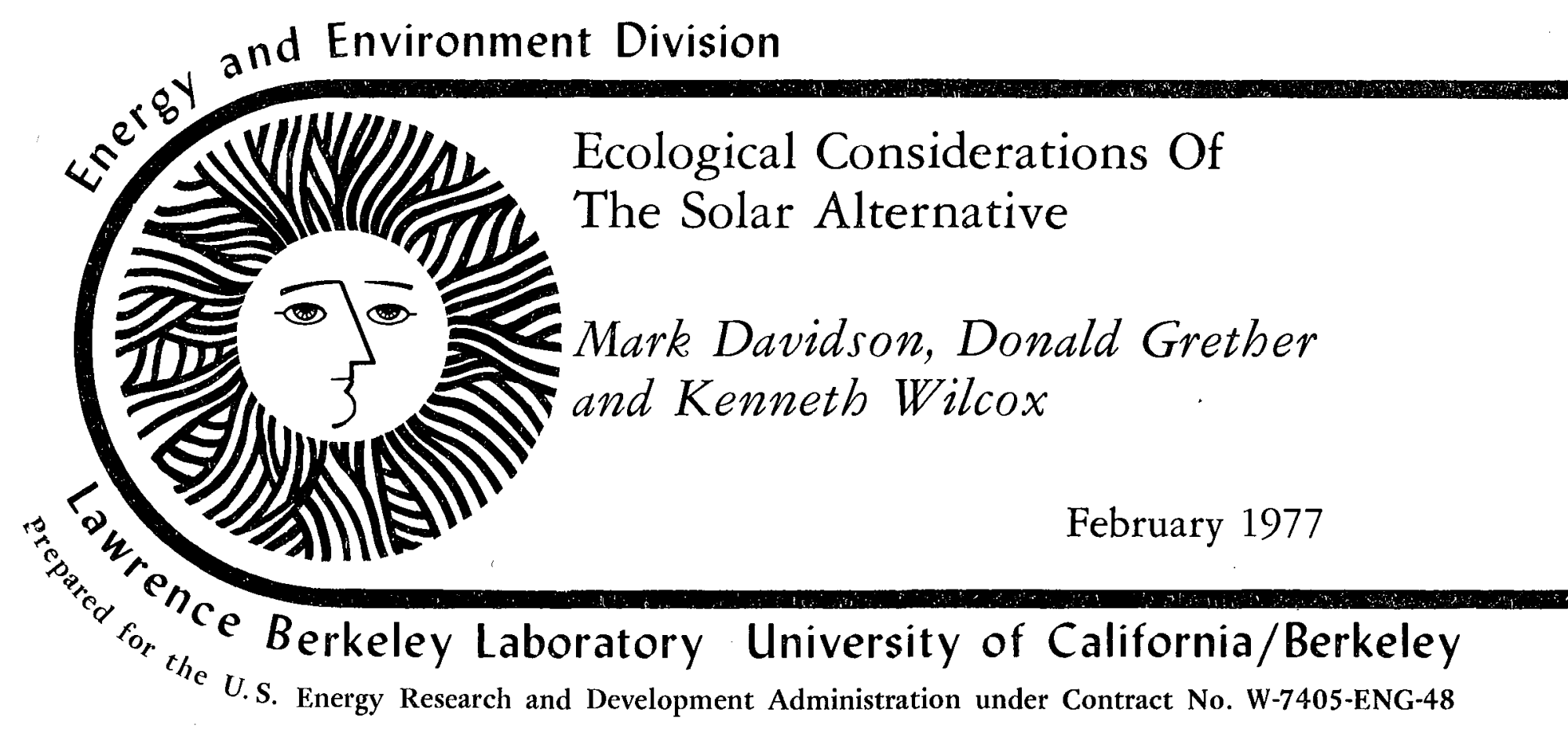




\section{LEGAL NOTICE}

This report was prepared as an account of work sponsored by the United States Government. Neither the United States nor the United States Energy Research and Development Administration, nor any of their employees, nor any of their contractors, subcontractors, or their employees, makes any warranty, express or implied, or assumes any legal liability or responsibility for the accuracy, completeness or usefulness of any information, apparatus, product or process disclosed, or represents that its use would not infringe privately owned rights.

Printed in the United States of America

Available from

National Technical Information Service

U.S. Department of Commerce

5285 Port Royal Road

Springfield, Virginia 22161

Price: Printed Copy $\$ 5.50$; Microfiche $\$ 2.25$ 
0000703993

B-1

\title{
ECOLOGICAL CONSIDERATIONS OF THE SOLAR ALTERNATTVE
}

\author{
Mark Davidson \\ Donald Grether \\ Kenneth Wilcox
}

\author{
Lawrence Berkeley Laboratory \\ University of California \\ Berkeley, California 94720
}

This work was done with the support from the U.S. Energy Research and Development Administration. 
B-2

\section{TABLE OF CONTENTS}

I. Introduction

II. The Main Solar Technologies

III. Direct Ecological Impacts

IV. Indirect Ecological Impacts

V. Conclusion

Appendix I

References 


\section{INTRODUCTION}

Solar energy offers hope for a future in which energy is relatively plentiful, renewable, nearly carte1-proof, and available to large segments of the world population. At our present level of understanding, solar energy appears relatively benign environmentally compared to other energy technologies such as burning of fossil or synthetic fuels, nuclear power, etc. Included in the generic term solar energy are: solar thermal conversion to electricity, photo-voltaic conversion, wind energy, bioconversion, direct heating and cooling of buildings, ocean thermal energy, and direct agricultural and industrial process heat. Solar energy may offer some relief to a world that has been beset by a host of harmful and often disastrous activities of modern industrialized man. Its development will rely heavily on conventional technologies and materials such as steel, glass, and concrete. It may prove to be a somewhat more labor intensive enterprise than the present energy technologies.

Most solar energy conversion technologies would not degrade the environment in the manner of conventional energy technologies. However, there is potential for harmful effects due to indirect causes, efforts to reduce costs, accidents, manufacturing and transporting equipment, extracting and processing of raw materials, large 1 and areas required for some conversion processes, and alterations to the marine or terrestrial environment from other processes.

Solar radiation is a somewhat diffuse energy source. The 
radiation flux incident on a surface above the earth's atmosphere is about $1.4 \mathrm{KW} / \mathrm{m}^{2}$. The flux hitting the earth's surface is reduced from this by some amount that depends heavily on atmospheric conditions. The total solar energy incident on the earth is immense; about .167 quadrilion Btu per second. At this rate, an amount of energy equal to the annual energy consumption of the United States hits the earth every 8 minutes. Of course, collection of most of this energy is impractical. Typical locations in the continental U.S. receive between 150 and $250 \mathrm{~W} / \mathrm{m}^{2}$ on a horizontal surface as a 24 -hour annual average. Providing all of the energy needs of the U.S. (about $75 \times 10^{15}$ Btu) with solar energy at $10 \%$ conversion efficiancy would require (for the $250 \mathrm{~W} / \mathrm{m}^{2}$ figure), a land area of about $10^{5} \mathrm{Km}^{2}$, or about $1.3 \%$ of conterminous U.S. Large collector areas and consequent1y large amounts of materials would be needed to convert substantial amounts of solar radiation into more useful energy forms. Methods that take advantage of natural collection processes, such as wind and ocean thermal gradients, would also have large material requirements.

Technologies which are especially land area intensive are solar therma1, photovoltaics, and bioconversion. Substantial disruption of local ecosystems will result from the implementation of these technologies, and this effect may prove to be of considerable concern. Ocean thermal power, through not requiring large marine surface areas, will probably affect ecosystems over large areas. Wind energy appears re1atively benign from this point of view. However, aesthetic considerations of large arrays of very large wind turbines may prove a deterrent to this technology. All of the solar technologies require great 


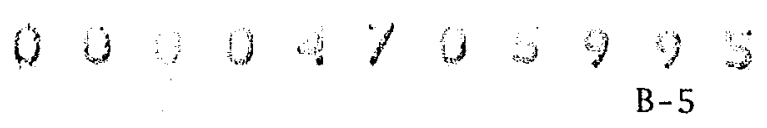

amounts of materials. The production of these will cause pollution that must be included in environmental evaluations.

Power from the sun may be utilized in several different ways and each of these has its own distinctive environmental impact. In Section II the main solar technologies will be described. In Section III direct ecological and environmental impacts of these technologies will be considered. Section IV contains some comments on indirect effects and section $\mathrm{V}$ some closing comments.

II. THE MAIN SOLAR TECHNOLOGIES ${ }^{1,2,3,4,5}$

A. Solar Thermal Power

Solar thermal power production typically utilizes various focusing devices to concentrate solar radiation and then transfer the energy of this radiation to a working fluid which drives a heat engine to produce mechanical or electrical energy. There are two main types, the parabolic trough collector and the central receiver collector. The parabolic trough focuses sunlight onto a line with concentration ratios of about 10-100 to 1 . The parabolic mirror surface may be mounted on a single axis and rotated to track the sun. In the central receiver design sunlight is focused by a large field of heliostats (mirrors mounted on sun tracking platforms). The concentration ratios achieved in this way are much greater, about 500-1500 to 1 . However, the heliostats are more complicated in that they must rotate about two axes. Because of the higher temperatures that can be achieved, and the lower material requirements of the central receiver design, it is currently favored over the parabolic trough for large scale power 
generation. The economic feasibility of solar thermal power is currently a matter of debate, with most of the cost in the heliostat field. However, it is generally acceptable that this technology will not be competitive until at least the late 1980's. Typical 1and areas for $100 \mathrm{MW}$ intermediate load power plants are about $2 \mathrm{~km}^{2}$. For a base load plant the area would be about $3-4 \mathrm{~km}^{2}$.

B. Photovoltaic ${ }^{\text {Ce11s }}{ }^{1,6,7}$

Photovoltaic cells are based on semiconductor materials that will generate a current when exposed to sunlight. The ce11s current1y in most common use (e.g., in the space program) consist of thin layers of silicon sliced from a single crystal, with suitable electrodes attached. These cells have routine conversion efficiences of $12-14 \%$, with a theoretical maximum for sun1ight of about $22 \%$. The 1 ifetime of these cells is expected to be 15 years or more. The cost of arrays of such ce11s must decrease by at least a factor of 100 for them to become economical for large-scale electricity generation. The current manufacturing process is inherently energy-intensive and expensive. It is not certain that mass-production will ever be able to lower the price sufficient1y to be competitive.

Efforts are currently underway to develop a cheaper process for single crystal silicon. The EFG (Edge-Defined, Film-Fed Growth) process for producing "ribbons" of silicon crystal is one such candidate. Other materials under investigation include polycrystalline thinfilm silicon, gallium arsenide, indium phosphide and cadmium sulfidecopper sulfide. So far, none of these cells has the necessary combination of high efficiency, long lifetime and low cost. 
An alternative to arrays of $10 \mathrm{w}$ cost cells is to use concentrators (e.g., mirrors) to reduce the area of cel1 needed for a particular power output. Concentration factors of $\sim$ 1000-2000 appear feasible; making the cost of the solar cells negligible. However, just as for solar thermal power, the concentrators are not currently economical.

C. Ocean Thermal Power $^{1,8}$

Tropical oceans develop substantial vertical temperature gradients. At a depth of $1 \mathrm{~km}$, one finds temperatures as much as $25^{\circ} \mathrm{C}$ cooler than the surface. In the vicinity of the U.S., the Gulf Stream has a temperature difference of $\sim 20^{\circ} \mathrm{C}$. These gradients may be used to generate power, by running a Rankinecycle heat engine between the warm surface water and the cold deep water.

Due to Carnot efficiency 1imitations, locations with the largest thermal gradients are desirable. The cold water intake would be at perhaps 600 meters depth. Efficiencies on the order of 2 to $3 \%$ are expected. Consequently, large volumes of water must be pumped, requiring huge pipes and hoat transfer surfaces.

As an example of the rates required, for a $20^{\circ} \mathrm{K}$ temperature difference and $2 \%$ efficiency, a theoretical lower 1 imit on the flow rate is about $2 \times 10^{5} \mathrm{~m}^{3} / \mathrm{hr}$ for a $100 \mathrm{MW}$ power output. In practice the flow rate could be considerably larger 
than this. These rates are not significantly greater than the flow rates for the hydroelectric dams.

In order to supply electrical power to a land-based grid, the ocean thermal p1ant would need to be moored or dynamically positioned within cable length of shore. For the conterminous U.S., the plants would then in practice be restricted to the Gulf stream with its relatively lower temperature differences and high currents. Another possibility is for the plant to manufacture energy intensive chemicals (hydrogen, ammonia, aluminum), which would be transported to shore by ship. In this case, the plants would probably be located in tropical waters.

D. Wind Energy ${ }^{1,9}$

Power may be extracted from the wind by a variety of devices. Output is usually either mechanical (shaft horsepower) or electrical, a1though it may be desirable in some instances to generate the output in the form of thermal energy. Potential applications range from modest sized machines in rural or remote areas, to large arrays of large machines tied to the power grid. A wide variety of horizontal axis and vertical axis wind machines have been developed, although the possibilities have by no means yet been exhausted. Most familiar are the traditional Dutch windmill, the American multivane fan used for water pumping in the Western U.S., and the high-speed propeller type used to produce electricity (all horizontal axis machines), and the vertical-axis Savonius rotor similar to the common wind-driven building ventilator tops. 
Energy flux in the wind varies as $\frac{1}{2} \rho V^{3}$, where $\rho$ is the density of air and $V$ is the wind velocity relative to the ground. The cubic dependence on velocity means that a small increase in wind speed results in a much larger increase in available power; wind machines are thus highly site dependent. The theoretical maximum extractable power for horizontal axis machines is 59.3\% of the total. Typical efficiencies are more 1ike 35\% for highspeed electricity-generating wind machines and appreciably less for the lower-speed mechanical-output machines.

Wind energy at a typical moderately-windy location is roughly as diffuse as solar energy. Total power in an $18 \mathrm{mph}$ wind is about $1000 \mathrm{~W} / \mathrm{m}^{2}$ of blade sweep area. Production of 1 arge amounts of power will require large structures and material requirements even in relatively windy areas such as the midwestern U.S. The dimensions of an array of wind turbines will depend on the spacing between turbines. Current estimates are that this spacing will be about 10 blade diameters for horizontal axis machines.

E. Solar Heating and Cooling ${ }^{10,11}$

Decentralized heating and cooling of buildings by solar energy is already economical in some areas, and should become more widespread with mass production of solar equipment and continued rise in fuel prices. Flat plate collectors are usually preferred due to cost considerations, but moderate radiation concentration may be preferred in some instances to obtain the higher temperatures required to operate absorption air conditioners. Collectors will be located predominately on the roof of the building to be heated or cooled. Air or a liquid will be used to 
transfer the heat to the building interior or to an air conditioner, either directly or through the intermediary of a heat storage medium. A backup energy source will usually be provided for periods of inadequate storage.

Instead of the active solar heating and cooling described above, some buildings may employ passive heating and cooling. Use is made of high thermal mass and natural convection and radiation in the building to moderate the temperature swings that would otherwise occur. While generally cheaper to provide, passive heating and cooling can not maintain the very narrow temperature ranges obtainable by active systems.

F. Bioconversion ${ }^{12,13}$

Organic material may be burned directly to produce heat and electricity, or first converted to a liquid or gaseous fuel for later burning. Conversion of biological waste material such as forest products or urban and agricultural wastes could provide a significant, though relatively small fraction of the nation's energy requirements.

Bioproduction, the deliberate growth of organic material for conversion, could also be accomplished. Terrestrial "energy farms" might use high yield food crops such as sugar cane or corn, trees harvested every few years, or grasses. These materials would be converted much as for the organic wastes. Another possibility is a plant that yields a fluid rich in hydrocarbons, similar to (but lower in molecular weight than) the latex from rubber trees. Marine-based bioproduction using giant kelp has 


$$
00 \%+90949
$$

received some attention.

G. Agricu1tura1 and Industrial Process Heat

Solar energy has numerous applications of sma11 or moderate scale in industry and agriculture. Examples are crop drying, irrigation pumping, production of industrial process steam with potential for by-product power generation, high temperature heating, and de-salinization. The solar devices used for these app1ications would be similar to those for solar thermal power and solar heating and cooling. 
III. DIRECT ECOLOGICAL IMPACTS

A. Solar Thermal Power

Solar thermal power plants will most 1ikely be constructed in arid or semiarid regions, where the ecosystems tend to be rather fragile. The most obvious effect is that large land areas (see Section IIA) would be roughly half-covered with heliostats. The native ecosystems in such areas would essentially be destroyed. The replacement ecosystem will depend on, among other things, the details of the heliostat field. Some designs would require the land to be paved, or to have herbicides app1ied to prevent vegetation from interfering with heliostat operations. Other designs could have vegetation under the mirrors. The micro-climate under the mirrors will be cooler, less windy, and probably more moist than for natural conditions. This more benign environment might support different types of plants, or faster growth rates than normal. Some people have suggested that the heliostat fields would be suitable for agriculture

The ecological acceptability of devoting land in semi-arid areas to heliostat fields will depend on many factors; the impact from the specific siting of the solar facility (e.g., the presence or absence of endangered species), the impact of the construction of the facility, and the impact of the expected increase in industry and human population. There have not been specific studies of these impacts for solar thermal plants. However, many of the possible effects are similar to those of off-road vehicles, which have been a major ecological concern in recent years. ${ }^{14,15}$ Studies of desert ecology per se are extensive although not well organized 


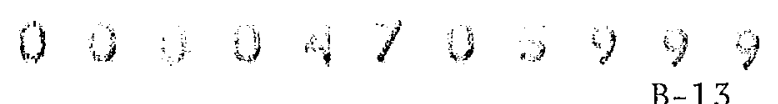

as a body of knowledge. A fairly up to date review is given by McGinnies. 16 Information on geomorphology, wind and water erosion, drainage systems, hydrology, and soils of deserts may be found in Cooke. ${ }^{17}$ Possible impacts to desert ecosystems are as follows.

1) Destruction of burrowing animals and their habitats during construction. This direct kill of wildlife is an important problem because many desert animals spend most of the sunlit hours underground, where it is cooler and moister than the hot arid surface. The heat of the desert sun rarely penetrates more than a few inches beneath the surface. The magnitude of the effect on burrowing animals will depend upon the amount of generating capacity installed in the region and the tonnage of the trucks used for hauling. It will also depend on soil strength at the site and on the type and width of roads which will be used for hauling. Another important factor will be the population of animals at the site and their burrowing habits. Sites near water holes or springs are 1ikely to contain large numbers of animals whereas playas or dry drainage basins have relatively little animal or plant 1 ife, and may therefore be more appropriate locations for solar plants. Playas flood on occasion presenting a technical problem for such siting.

2) Breaking the desert crust by off-road vehicles. Fine materials are abundant in the desert, but they are usually formed at the surface into a thin crust. It protects the underlying fines from erosion, especially wind erosion. This crust may be up to $6 \mathrm{~mm}$ thick. It is quite widespread, but good estimates of exactly what percentage of the desert surface are covered by it are not available. It is delicate and fragile in many places, 
and water can penetrate it. The details of how the crust forms are still a matter of some debate. Compaction resulting from rainfall has been suggested as a mechanism for its formation. It is bound by chemical cementing of grains which may, in some areas, be promoted by 1 ichen or algae growth. Fungal filaments may also contribute to the crust in areas where there is organic matter in the soil.

The presence of construction vehicles and workers in the vicinity of the solar plant will damage this crust wherever it exists and this will accelerate wind erosion. In addition, the increased population of the region resulting from the presence of the solar plant may lead to increased recreational demands on deserts with more off-road vehicle activity, and its destructive effects on desert crusts. Conservationists are present1y trying to limit this off-road traffic (for example the annual Barstow to Vegas motorcycle race) and if they are successful then this 1atter problem will be considerab1y reduced.

Since the crust acts as a sealant for the fines beneath the surface, when the crust is broken an increase in atmospheric turbidity can be expected. With increased wind erosion, degradation of soil quality can occur, resulting in less flora and fauna in the area affected.

3) Destruction of desert pavement. Over a period of many years, many areas of deserts have developed a surface of fairly densely packed pebbles and stones known as desert pavement. ${ }^{18}$ It forms from pebbles and cobbles, accumulated on dry land as a 


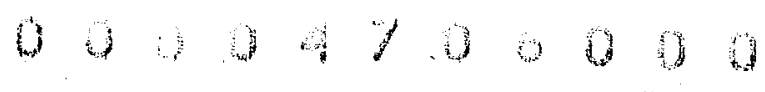

$\mathrm{B}-15$

result of wind or water carrying away the finer particles of sand, silt or clay* The stones of the pavement typically vary in size from $0.5 \mathrm{~cm}$ to $20 \mathrm{~cm}$. They are cemented together or encrusted with various salts, gypsum, lime and silicates, and are often coated with a desert varnish. The pavement retards erosion and water runoff. When it is broken by off-road vehicles, considerable wind and water erosion can result. Water runoff during the storms will decrease the sparse water available for 1 ife in the vicinity.

4)Hydrological effects. The water cycle in arid regions is extremely important to all forms of wild1ife, and any modification of this cycle could affect the local ecosystem. A very rough picture of the hydrological cycle is as follows. ${ }^{19}$. Rains usually occur in mountains or over alluvial fans, charging the water table in the high grounds. The ground water then flows slowly as a result of gravity and pressure forces to lower-1ying basins or plains. Large amounts of water are evaporated in the desert playas, which are low-lying saline flats covering vast areas and are the remnants of ancient lakes. These playas may be suitable for solar energy for several reasons. From an ecological vi.ewpoint, these areas are low in wild1ife so that damage to the ecosystem will be minimal. From a technological viewpoint, the areas are very flat so that the need for grading will be reduced; and they have 1ittle precipitation. However, as mentioned in Section IIA, the playas are subject to flooding.

In the Wentworth particle size classification scheme the grid sizes which define various sizes are: Boulder $>256 \mathrm{~mm}, 256 \mathrm{~mm}>$ cobble $>64 \mathrm{~mm}, 64 \mathrm{~mm}>$ pebble $>2 \mathrm{~mm}, 2 \mathrm{~mm}>\mathrm{sand}>1 / 16 \mathrm{~mm}>\mathrm{sil} \mathrm{t}>1 / 256 \mathrm{~mm}$, $1 / 256 \mathrm{~mm}>\mathrm{clay}$. 
Solar thermal plants will shade the surface soil and reduce the intense evaporation that normally takes place. This will be especially true for the water held in the soil after a rainfall. The water table in the playas tends to be quite close to the surface. If solar thermal plants are built in the playas, they may increase the height of the water table to some extent.

5) Water consumption. Solar plants which utilize Rankine cycle engines will require some type of cooling device for the condensation stage. Once-through cooling can be used if a large body of water is nearby, but considerable evaporative water losses will occur. Alternatives are wet cooling towers (either mechanical draft or natural draft), cooling ponds, and dry cooling towers. With the exception of dry cooling towers, all of these require substantial amounts of water. For example, a 100 MW plant using mechanical draft cooling would require about $2.36 \times 10^{5} 1$ iters/hour of water for evaporation. Dry cooling towers, on the other hand, are substantially more expensive. Thus there is a potential for a further strain on the scarce water supply in the southwest.

A possible alternative to the Rankine cycle is the open Brayton cycle ( a gas turbine with air as the working fluid). While requiring essentially no water for cooling, such a system (as presently conceived) would need to burn fossil fuels during periods of sporadic cloud cover to avoid thermal transients. The technology is not lar enough advanced, and the consequences not sufficiently well understood, to judge whether, from an ecological standpoint, the burning of fossil fuels would be superior to water 
consumption.

Additional information on water availability in the southwest is given in Section IV.

6) Effects on birds. The glare from heliostat fields in the flight path of birds may affect their ability to fly and navigate. Some birds may venture close to the central receiver and be burned or blinded by in intense radiation. It is impossible to specify what will happen without actual data collection on site.

7) Climatology. Solar power plants of the central receiver typos will, to some extent, alter the climate in their immediate vicinity. The micro-climate under the heliostats has been discussed above. Other possibilities include alterations to local convection currents from heat sources (cooling towers and receivers), and (for evaporative cooling) the creation of fog banks or clouds. Preliminary indications are that these effects are not likely to be significant for individual plants.

Large numbers of solar plants could alter regional climate by changing the ground albedo, moisture content of the atmosphere, and surface roughness. Massive global use of solar plants could conceivably alter the global climate. The amount of land area that would need to be covered by the plants to have a regional or global impact is essentially not known. However, by analogy to other types of man"s activities (e.g. large cities and replacement of forests by agricultural areas), one would expect calculable effects to require 
1and areas in excess of any near-term expectations for the technology.

B. Photovoltaic Devices

Photovoltaic devices could be installed in arid regions as would solar thermal plants. These devices might be installed with concentrating heliostat fields to cut down on semiconductor requirements, or they may simply be exposed to the natural radiation flux. Somewhat greater collection areas would be required than for central receiver devices because of lower overall efficiences (10-15\%) and also, for non-tracking arrays, the incident flux is reduced by a geometric factor. Ecological effects similar to those of solar thermal would be expected. In addition, there are some potential problems from the cell materials.

Silicon cells are essentially non-toxic, but the manufacturing process requires the use of toxic materials (e.g., silanes and halogens). These substances are carefully controlled for occupational health reasons, but would be an environmental hazard if accidently released. Some proposed cells such as $\mathrm{CdS}-\mathrm{Cu}_{2} \mathrm{~S}$, CdS-InP, and GaAs are partial1y composed of environmentally dangerous substances and as a result the mining, manufacturing, and 


\section{$00007000 \%$}

distribution of these must be handled with care. The solar cells or their encapsulation materials may degrade in time, and their decomposition under natural conditions or during a fire may produce toxic products.

Photovoltaic cells could also be used on individual buildings. Here, erosion of solar cell materials or release of combustion products during fires could constitute a hazard to the urban ecosystem. However, the health hazards of such releases are of considerably more concern.

\section{Ocean Thermal Power}

An ocean thermal plant is almost certain to alter the ecosystem in the plant's immediate vicinity. A more speculative possibility is that a large number of plants would modify ocean currents or temperatures, and, in turn, regional or global ecosystems. The local effects will be considered first.

During normal operation of ocean thermal plants, considerable amounts of cool water from the ocean depths would be pumped to, or close to the surface. This pumping is expected to produce effects similar to natural upwellings, such as those occurring in the Canary Islands, off the coasts of Southern California and the Baja peninsula, and off the coast of Peru. These upwellings produce a great abundance of marine life since nutrients are often the limiting factor determining population densities. (Without upwelling or some other mechanism for mixing, nutrients accumulate at deep levels, due to the continuous transfer of material from 
the surface.) Proponents of ocean thermal power consider the anticipated enhanced marine growth to be a new source of food. It is, however, too early to judge whether this side effect will be a desirable addition to the marine ecosystem.

During the pumping, deep ocean species will be entrained in the cold water pipe. The extent of this problem (e.g., endangering a particular species) will depend on siting, and the density of plants. Biocides may be used to prevent fouling of the heat exchangers. The biocides may be harmful to other species in the vicinity of the plant. Ocean thermal plants will probably use working fluids other than water, and these fluids will be released by leaks and accidents. The current1y favored fluid is ammonia which, when diluted sufficiently, is a nutrient. Ocean thermal plants will be navigational hazards for ships in the area. This will probably result in an increase in the number of shipwrecks, oil spills, and chemical releases which will have quite undesirable ecological effects. This problem could be partially alleviated by forming shipping lanes and increasing navigational aids in the area.

Section IIC mentioned the possibility that tropics-based ocean thermal plants would manufacture energy-intensive materials. Some material-candidates (such as aluminum) would involve processing ores shipped from land. The waste products might be dumped into the ocean, and could constitute a hazard to the marine environment.

Van Hipple and Williams have proposed ${ }^{20}$ that large amounts 


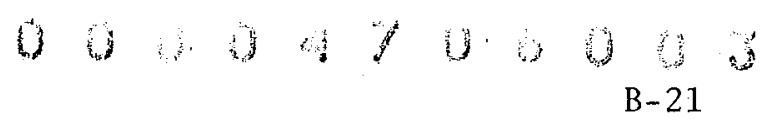

of carbon will be brought to the surface by the upwelling of the cold water. This carbon would be released to the atmosphere as $\mathrm{CO}_{2}$, at roughly $1 / 3$ the rate of an equivalent fossil fuel plant. $\mathrm{CO}_{2}$ is rarely the limiting factor in determining population densities and will probably not impact ecosystems significantly. However, the release will add to the $\mathrm{CO}_{2}$ buildup in the atmosphere.

Next, we consider the effects on ocean circulation patterns. The tropical oceans are immense and relatively slow moving (currents less than one knot). It is difficult to imagine that enough ocean thermal plants could be located in these waters to affect their circulation patterns. However, if the plants are to directly supply the U.S. with electrical power, then they will be located in the Gulf Stream. The plants could, at some level of use, affect the pattern of the Gulf Stream and thus the heat flux from the equator to the poles. The importance of this effect is complicated by several feedback mechanisms and by the overal1 lack of knowledge concerning the ocean-atmosphere system. It is generally thought, however, that sma11 changes in the heat balance of the poles are magnified somewhat by the positive feedback resulting from increasing or decreasing ice cover.

The climates of Western Europe and the Eastern United States are largely determined by the Gulf Stream. Changes in the heat content or pattern of the current by the ocean thermal plants could thus significantly afrect these rogions. (The plants might affect the Gulf Stream both by direct removal of energy and by mixing of warm surface waters and cold water from the depths.) One example of a possible effect 
on ecosystems concerns fish populations. The $10^{\circ}$ isotherm of the North Atlantic roughly separates the Artic or Boreal marine life forms (e.g., cod, haddock) from the temperate water species (e.g., European hake, Dover sole, and mackere1). ${ }^{21}$ Changes in the isotherm would hence alter the distribution of marine life.

The political problems arising from altering the Gulf Stream arc likely to overshadow the ecological ones. But, for whatever reason, the implications of placing large numbers of ocean thermal plants in the Gulf stream require considerable attention.

\section{Wind Energy}

Wind generators for central station electrical power will be sited at locations where wind velocities are high. Since significant amounts of kinetic energy may be taken from the wind, climate modification appears possible. Nothing definite can be said except that turbulent eddies on the scale of the wind collector blades or larger are likely to be dissipated, their energy being absorbed by the wind generator system. The construction of wind generators in large numbers in remote areas is certain to disrupt the local ecosystem to some extent, simply due to the paving and grading of the surface, the transportation of materials and equipment to the end site, the construction of transmission lines, etc. Fast spinning blades may be a real physical danger to birds in the region, which may fly into the blades by accident or be confused or disoriented by them. The noise level of some generator designs may prove harmful or disrupting to some wildlife in the region. Compatibility of large wind turbine arrays with agricultural ecosystems, such as grazing land, may be a problem. 


\section{9

The most significant impact on the environment is likely to be the mere physical presence of large numbers of very large structures. The aesthetic acceptance or rejection of the arrays may (aside from economics) prove to be the factor that determines the extent of the use of wind turbines for central station electrical power.

\section{E. Solar Heating and Cooling}

Solar heating and cooling of buildings appears to be a relatively benign technology environmenta11y. Heat transfer, heat storage, or refrigeration fluids will be released into the environment by accidents and periodic maintenance. The severity of this problem will depend on design, density of heating and cooling units, and the nature of the waste disposal system. Depending on the materials used to construct the system, some harmful compounds such as plastics or anti-freeze may be released in the event of a fire or as a result of normal degradation due to the elements. Because of the large number of diverse designs for heating and cooling systems, it is difficult to be more specific about these effects.

\section{F. Bioconversion}

There is little literature on the subject of environmental problems associated with bioconversion. Danyluk's work ${ }^{22}$ is one of the few studies in this area. Bioconversion, like other solar technologies, can be utilized in diverse ways. Various processes may be used to convert organic wastes into useful fuels. These include fermentation, pyrolysis, catalytic gasification, biophotolysis, etc. In addition, the organic material could simply be 
burned. Each of these technologies has, to some extent, foreseeable environmental problems.

Combustion of fuels at final end use point occurs in all bioconversion schemes. The environmental aspects are similar to the burning of fossil fue1s. Combustion will produce air pollutants, including particulates, toxic gasses, $\mathrm{NO}_{\mathrm{x}}$, $\mathrm{SO}_{\mathrm{x}}$, volatile trace metals, and sma11 amounts of aromatic compounds. $\mathrm{CO}_{2}$ should not be a problem since, under steady state conditions, the carbon will be recycled in new plant material. Sulfide emissions will be substantially lower than for fossil fuel combustion, for the same amount of energy production.

Bioconversion may use urban and agricultural waste biomass, or energy plantations may be built to grow biomass specifically for the purpose of energy conversion. Consider the latter possibility, approximate1y $12 \%$ of the total U.S. 1 and area would be required to produce the current U.S. energy needs assuming $1 \%$ photosynthetic conversion efficiency. For currently realizable efficiences approximately 6\%, $25 \%$ and $124 \%$ of the land would be needed if the crop grown were sugar cane, scotch pine and cool temperate forests respectively ${ }^{23}$

The land currently devoted to crops is about $16 \%$. The amount of water necessary to irrigate the energy plantations would be comparable to. agricultural needs per acre. In the case of sugar cane, extensive industrial fertilization would be needed. Bioconversion farms may compete with agriculture for 1 and and water in some regions. Extensive development of land-based bioconversion may severely strain the water supply systems in many areas of the nation and the world. As with agriculture, pest control measures may harm desirable species. Energy plantations will produce simplified ecosystems, with many species 


\section{$000070 b \mathrm{~B}_{25}$}

significantly reduced in population. Poor management could eventually result in soil erosion.

For the cases of agricultural waste and energy plantation biomass, soils may be degraded by the loss of humus and increased fertilization would then be required. This fertilization may affect water quality in the area. There is currently a concern that in the long run the soil will suffer permanent damage.

The use of cultivated or waste organic materials will require extensive land area for storage and pretreatment of material prior to conversion. This storage may create problems of pest control and disease vectors. Environmenta1ly acceptable ways of disposing of combustion residue (i.e., ash) will have to be found. For agricultural and forest waste, or for bioproduction, this ash contains valuable nutrients and would probably be recycled as fertilizer, but this needs further study. For urban wastes, heavy metal contamination may preclude recycling. Most bioconversion schemes would require the transport of large amounts of material, possibly leading to significant environmental problems.

Many of the environmental problems posed by large fermentation facilities are similar to those of urban and industrial sewage and waste water treatment plants. Release of odiferous and toxic gases, storage requirements, release of material and harmful microorganisms, purification of water before final release, and disposal of waste sludge are some of the problems. Poor management or planning of the system could lead to significant alterations in the local biota. 
environmental impacts similar to those expected in coal gasification and 1iquefaction. Control of atmospheric pollutants will be necessary, and provisions made for disposal of solid waste.

Algae ponds are a possible source of biomass production. More speculatively, algae have been proposed as a means of directly producing $\mathrm{H}_{2}$. If these approaches were carried out on a. large scale, then siting of algae ponds, disposal of a1gal wastes, leakage of materials to nearby water supplies, and supplying algae with nutrients are likely to lead to environmental problems.

\section{G. Agricultural and Industrial Process Heat}

The diversity of small scale applications which solar energy might have in agriculture and industry makes it difficult to be specific about possible environmental effects. The situation is similar to heating and cooling of buildings. There is the possibility of the release of heat transfer, heat storage, or refrigeration fluids into the environment. Also, harmful compounds may be released in the event of a fire or as a result of normal degradation due to the elements. 
04034740006

IV. INDIRECT ECOLOGICAL IMPACTS

Associated with the production of solar energy equipment will be certain amounts of pollution resulting from industrial activity. This is an important factor since the material requirements in many solar technologies are immense, compared to conventional technologies. The most common materials which will be used are steel, glass, and cement. The effluents associated with these materia1s will be distributed in the regions where they are produced. At present, the regions are primarily in the eastern and midwestern industrial states, especially Illinois, Pennsylvania, Ohio and New Jersey. With vast solar construction in the southwest, it is likely that some industry will relocate there. The importance of the relocation is very difficult to estimate in the long term and so it is almost impossible to say anything meaningful about the regional distribution of these effluents.

The emissions associated with the production of steel, glass and concrete have been tabulated in various sources. Good descriptive accounts for these and other materials are given in Ref. 24. Tables I, II and III give effluents per ton of output as industry averages. This data was compiled by the Energy Reference Group at Brookhaven National Laboratory. The data is far from complete, but is probably the best presently available.

A good examp1e of materia1-intensive solar technology is solar thermal power. To estimate the material requirements for this case, consider the construction of 10,000 megawatts per year of intermediate load electric power plants using the central receiver design. Using estimates provided by Aerospace Industries, 
TABLE I

Iron and Stee ${ }^{*}$

\begin{tabular}{|c|c|c|}
\hline No. & Effluent (Unit) & Amount \\
\hline 1. & Non Degradable Organics (Tons) & $4.5 \times 10^{-4}$ \\
\hline 2. & $\mathrm{SO}_{\mathrm{x}}$ (Tons) & $4.63 \times 10^{-4}$ \\
\hline 3. & CO (Tons) & $8.64 \times 10^{-3}$ \\
\hline 4. & Total Air Pollutants (Tons) & $6.47 \times 10^{-2}$ \\
\hline 5. & Other Dissolved Solids (Tons) & $7.13 \times 10^{-5}$ \\
\hline 6. & Suspended Solids (Tons) & $1.21 \times 10^{-3}$ \\
\hline 7. & ${ }^{N O}{ }_{x}$ (Tons) & $4.54 \times 10^{-2}$ \\
\hline 8. & Energy Demand (Btu) & $2.23 \times 10^{7}$ \\
\hline 9 . & Ammonia (Tons) & $6.2 \times 10^{-5}$ \\
\hline 10. & Cyanide (Tons) & $6.2 \times 10^{-6}$ \\
\hline 11. & Phenol (Tons) & $3.08 \times 10^{-6}$ \\
\hline 12 . & Oil and Grease(Tons) & $4.5 \times 10^{-4}$ \\
\hline 13. & Particulates (Tons) & $1.02 \times 10^{-2}$ \\
\hline 14. & Biological Oxygen Demand & N.A. \\
\hline 15. & Acid & N.A. \\
\hline 16. & Chemical Oxygen Demand & N.A. \\
\hline
\end{tabular}

${ }^{*}$ Effluents per ton of Raw Iron or Steel.

Tota1 Production $=1.33 \times 10^{8}$ in 1972

N.A. - data not available 
$0004+706097$

TABLE II

\begin{tabular}{|c|c|c|}
\hline \multicolumn{3}{|c|}{ Glass* } \\
\hline No. & Effluent (Unit) & Amount \\
\hline 1. & Total Dissolved Solids (Tons) & $2.31 \times 10^{-2}$ \\
\hline 2. & Non Degradable Organics (Tons) & $1.25 \times 10^{-3}$ \\
\hline 3. & Total Solids and Organics (Tons) & $2.57 \times 10^{-2}$ \\
\hline 4. & ${ }^{\mathrm{NO}}{ }_{\mathrm{x}}$ (Tons) & $8.0 \times 10^{-4}$ \\
\hline 5. & $\begin{array}{l}\text { Aldehydes and Other Heavy } \\
\text { Organic Molecules (Tons) }\end{array}$ & $7.21 \times 10^{-5}$ \\
\hline 6. & P04 (Tons) & $3.2 \times 10^{-4}$ \\
\hline 7. & Suspended Solids (Tons) & $1.36 \times 10^{-3}$ \\
\hline 8. & Biological Oxygen Demand (Tons) & $1.2 \times 10^{-3}$ \\
\hline 9 . & Particulates (Tons) & $1.13 \times 10^{-3}$ \\
\hline 10. & $\mathrm{SO}_{\mathrm{x}}$ (Tons) & $4.19 \times 10^{-5}$ \\
\hline 11. & Total Air Pollution (Tons) & $2.01 \times 10^{-3}$ \\
\hline 12. & Energy Demand (Btu) & $2.88 \times 10^{7}$ \\
\hline 13. & Chemical Oxygen Demand & N.A. \\
\hline
\end{tabular}

*Effluents per ton of Glass produced.

Total glass production in 1972 was $1.41 \times 10^{7}$ tons.

N.A. - data not available 
TABLE III

\begin{tabular}{|c|c|c|}
\hline \multicolumn{3}{|c|}{ Cement ${ }^{*}$} \\
\hline No. & Effluent (Unit) & Amount \\
\hline 1. & Total Dissolved Solids (Tons) & $7.06 \times 10^{-5}$ \\
\hline 2 . & Chemica1 Oxygen Demand (Tons) & $1.2 \times 10^{-7}$ \\
\hline 3. & Tota1 Solids and Organics (Tons) & $1.67 \times 10^{-4}$ \\
\hline 4. & $\mathrm{NO}_{\mathrm{x}}$ (Tons) & $1.0 \times 10^{-7}$ \\
\hline 5. & Hydrocarbons (Tons) & $1.79 \times 10^{-5}$ \\
\hline 6. & $\begin{array}{l}\text { Aldehydes and Othér Heavy } \\
\text { Organics (Tons) }\end{array}$ & $6.7 \times 10^{-7}$ \\
\hline 7 . & Other Dissolved Solids (Tons) & $5.28 \times 10^{-5}$ \\
\hline 8. & Suspended So1ids (Tons) & $2.81 \times 10^{-5}$ \\
\hline 9 . & Biological Oxygen Demand (Tons) & $6.5 \times 10^{-7}$ \\
\hline 10. & Particulates (Tons) & $4.91 \times 10^{-2}$ \\
\hline 11. & $\mathrm{~S}_{\mathrm{x}}$ (Tons) & $3.1 \times 10^{-4}$ \\
\hline 12. & CO (Tons) & $4.13 \times 10^{-7}$ \\
\hline 13. & Total Air Pollution (Tons) & $4.95 \times 10^{-2}$ \\
\hline 14. & Energy Demand (Btu) & $3.62 \times 10^{6}$ \\
\hline 15. & Non Degradable Organics & N.A. \\
\hline 16. & Base (Tons) & $1.57 \times 10^{5}$ \\
\hline
\end{tabular}

${ }^{*}$ Effluents per ton of Cement produced.

Total cement production in 1972 was $5.67 \times 10^{8}$ tons.

N.A. - data not available 
TABLE IV

Approximate effluents for $10,000 \mathrm{~mW}$ of electric power due to heliostat materia1s production only - for Central Receiver Design. (Units are Tons)

\begin{tabular}{|c|c|c|c|c|}
\hline Effluent (Tons) & Stee1 & Glass & Cement & Total \\
\hline $\mathrm{SO}_{x}$ & 1,700 & 21 & 837 & 2558 \\
\hline $\mathrm{NO}_{\mathrm{x}}$ & 170,000 & 400 & 270 & $1.7 \times 10^{5}$ \\
\hline $\mathrm{PO}_{4}$ & N.A. & 160 & 0.0 & $>160$ \\
\hline Particulates & $3.8 \times 10^{4}$ & 565 & $1.3 \times 10^{5}$ & $1.7 \times 10^{5}$ \\
\hline Tota1 Air & $2.4 \times 10^{5}$ & 1,000 & $1.3 \times 10^{5}$ & $3.7 \times 10^{5}$ \\
\hline $\begin{array}{l}\text { Tota1 Solids and } \\
\text { Organics }\end{array}$ & N.A. & $1.3 \times 10^{4}$ & 451 & $>1.3 \times 10^{4}$ \\
\hline $\begin{array}{l}\text { Aldehydes and Heavy } \\
\text { Organics }\end{array}$ & 0.0 & 36 & 1.8 & 38 \\
\hline Suspended Solids & $4.5 \times 10^{3}$ & 680 & 76 & $5.3 \times 10^{5}$ \\
\hline $\begin{array}{l}\text { Total Dissolved } \\
\text { Solids }\end{array}$ & N.A. & $1.2 \times 10^{4}$ & 190 & $>1.2 \times 10^{4}$ \\
\hline $\begin{array}{l}\text { Biological Oxygen } \\
\text { Demand }\end{array}$ & N.A. & 600 & 1.8 & $>602$ \\
\hline $\begin{array}{l}\text { Chemica1 Oxygen } \\
\text { Demand }\end{array}$ & N.A. & N.A. & .32 & $>.32$ \\
\hline $\begin{array}{l}\text { Non Degradable } \\
\text { Organics }\end{array}$ & 1,690 & 625 & N.A. & $>2,300$ \\
\hline $\mathrm{CO}$ & $3.2 \times 10^{4}$ & N.A. & 1.1 & $>3.210^{4}$ \\
\hline $\begin{array}{l}\text { Other Dissolved } \\
\text { Solids }\end{array}$ & $2.7 \times 10^{2}$ & N.A. & 142 & $>412$ \\
\hline Ammonia & $2.3 \times 10^{2}$ & N.A. & N.A. & $>230$ \\
\hline Cyanide & 23 & N.A. & N.A. & $>23$ \\
\hline Pheno1 & 11.5 & N.A. & N.A. & $>11.5$ \\
\hline Oil and Grease & $1.7 \times 10^{3}$ & N.A. & N.A. & $>1.7 \times 10^{3}$ \\
\hline Hydrocarbons & 0.00 & N.A. & 48 & $>48$ \\
\hline
\end{tabular}

N.A. - Data not available 
the materials required annually for this level of construction are approximately as follows for the heliostats only:

$$
\begin{array}{lll}
\text { Stee } 1 & - & 3.75 \times 10^{6} \text { Tons } \\
\text { Glass } & - & 5 \times 10^{5} \text { Tons } \\
\text { Concrete } & - & 2.15 \times 10^{7} \text { Tons }
\end{array}
$$

These numbers are judgmental averages based upon the ERDA funded heliostat designs by Boeing, Honeywe11, McDonne11-Douglas and Martin-Marietta. Table 4 shows the effluents associated with this amount of materials production.

Estimates $^{25}$ of major air emissions for 1974 are:

$$
\begin{aligned}
& \text { Particulates - } 19.5 \times 10^{6} \text { Tons } \\
& \mathrm{SO}_{2} \quad-\quad 31.4 \times 10^{6} \text { Tons } \\
& { }^{N}{ }_{x} \quad-\quad 22.5 \times 10^{6} \text { Tons } \\
& \text { C0 - } 94.6 \times 10^{6} \text { Tons } \\
& \text { Hydrocarbons - } 30.4 \times 10^{6} \text { Tons. }
\end{aligned}
$$

The percentages which the solar effluents would add to these 1974 totals are:

$\begin{array}{lll}\text { Particulates } & - & .87 \% \\ \mathrm{~S}_{2} & - & .008 \% \\ { }_{\mathrm{N} 0} \mathrm{X} & - & .75 \% \\ \mathrm{CO} & - & .03 \%\end{array}$




\section{$00,0+\mathrm{HB}_{\mathrm{B}}-3 \mathrm{O}^{\mathrm{O}} \mathrm{O}$}

A preliminary comparison of the effluents produced by building a central receiver plant to the effluents released by generating the same amount of energy with coal, residual oil, and natural gas showed the following results where the energy output of the central receiver plant was calculated assuming a 50\% capacity factor and a 30 year lifetime. The central receiver leads to at least a factor of 10 less $\mathrm{NO}_{\mathrm{x}}$ than the fossil cases. It would produce about the same amount or more of $\mathrm{CO}$. It would produce about a factor of 10 less $\mathrm{SO}_{\mathrm{x}}$ than coal or $0 \mathrm{il}$, but would produce more than natural gas. It would produce substantially less hydrocarbons than coal or oil, but more than natural gas. It would produce about a factor of 2 less particulates than coal or residual oil, but slightly more than natural gas. These results assume that the fossil plants use state of the art pollution controls. Regarding particulates, the releases associated with central receivers come mainly from the cement industry and are mainly large particles, as compared with those from fossil fuel combustion. Because it is smal1 particles which are especially implicated in human respiratory effects, and because small particles appear to be more effective catalytic agents in chemical oxidation reactions, the comparison of particulate emissions is misleadingly biased in favor of fossil fuel plants.

The production of photovoltaic cells may have indirect ecological consequences. The reduction of $\mathrm{SiO}_{2}$ to metallurgical grade silicon requires large heat input and could result in sustantial thermal pollution. The refining of metallurgical silicon to high purity semiconductor grade silicon involves use of highly corrosive and toxic chemicals to form $\mathrm{Si}$ compounds that can be distilled ( $\left.\mathrm{SiF}_{4}, \mathrm{SiCl4}\right)$. Another commonly used compound, $\mathrm{SiH}_{4}$, is explosive. During deposition and doping of thin film Si solar cells, extremely poisonous substances like phosphorous trichloride, boron tribromide or arsene are used. The finished cell itself does not impose any environmental danger as it will revert back to $\mathrm{SiO}_{2}$ (ignoring the minute quantities of impurities), but the decomposition of protective enclosures may pose a threat. 
For other proposed cells such as CdS-Cu $2 S, C d S-I n P$ and GaAs, some of the materials are environmentally dangerous substances. The associated mining, manufacturing, and disposition of the materials must be carefully supervised.

Materials requirements for heating and cooling devices and agricultural and industrial process heat applications will be similar to those for central receiver plants, and no severe effluents problem is currently foreseen in their production. Ocean thermal technology is not sufficiently advanced to make definite predictions of materials requirements. To the extent that steel and other common building materials are used, there will be pollutants released during their production, but these effluents are not likely to be acute.

Since many solar facilities would operate best in arid regions, the problem of water supply is particularly important. Certain technologies are probably ruled out because of water scarcity. For example, substantial use of evaporative cooling devices (i.e., cooling ponds or wet cooling towers) would severely strain the lower and upper Colorado Basin's water supply. Much of the southwest is expected to face a water shortage of several percent of demand by the year $2000^{26}$ without including the effects of the solar energy industry. In addition, solar energy in the southwest will probably stimulate industry and population growth in the region, which. would place further demands on the water supply, In order to meet this demand, additional water supply programs would have to be instituted. These programs could involve desalinization plants". canals, climate modification, or some other scheme. These activities would have their own environmental impacts and could involve large 1and areas. Another possibility is that demand for water will place increased pressure to use more of the Colorado flow in the U.S.

Population growth and population shifts continue to threaten natural and agricultural ecosystems. Urban spraw1, and the slow but steady movement of the 


\section{0,07000}

population southward and westward are obvious examples. Extensive use of land-based solar energy conversion may accentuate this problem. In addition to the greater amounts of sunlight available in the south and west, solar heating and cooling of buildings and solar-supplied industrial process heat favor low-rise buildings and the use of relatively more land.

V. CONCLUSION

As for any of man's activities, solar energy conversion has environmental risks. Some of these risks are essentially unavoidable, such as the destruction or severe alteration of an ecosystem at least as large as the land area covered by a solar thermal or photovoltaic plant. Some of the risks can be avoided or minimized by design or regulation, such as the accidental release of working fluids. 0ther risks, such as the effect on the marine environment of ocean thermal plants, are highty speculative at our current state of knowledge and could prove either of minimal concern or a major obstacle to wide-spread use of the technology. Barring the latter case, most of the solar technologies appear environmentally acceptable when compared to the we11-known problems of conventional technologies. 


\section{APPENDIX I. IMPACT SUMMARY TABLES}

This section presents in tabular form a summary of the main ecological impacts of solar energy conversion, arranged by production technology. An attempt has been made to provide a rough relative ranking of the level of uncertainty surrounding each impact. Uncertainties are of two major types: a) in what manner is a given impact most likely to manifest itself (e.g., will the greatest effect of breaking the desert crust be surface erosion, air and water pollution, ruining the water table, or some other effect); and b) what is the magnitude of a given source term likely to be (e.g., what quantity of working fluids will be released by various types of solar collector). Our rankings of need for concern for each impact category consider the uncertainty of outcome (the risk), as well as a judgement of the seriousness of the impact even if it was certain to occur.

The rankings of uncertainty of outcome and need for concern for the impacts listed in all the tables have been rated on the same scale as nearly as possible. This scale applies only to solar energy technologies, and has been normalized to give a reasonable spread of concerns. Thus a "high" level of concern says nothing about whether such an impact would be considered high or low on a scale appropriate for fossil fuels or other energy sources. Even so, the rankings are approximate and somewhat subjective because of the absence of experience with largescale solar energy conversion. The preponderance of high or moderate rankings on some of the tables is due to the fact that many of the lower impacts were thought not to be important enough to include.

Because of the great diversity of potential bioconversion methods, 
this category has been arbitrarily divided into two tables for easier presentation. One table treats the growing of plants in "energy plantations" specifically for the purpose of converting it to some form of useful energy. The other table includes impacts associated with the collection of waste materials from municipa1, agricultural, and other sources, as well as impacts from the actual conversion processes (including biomass from energy plantations).

Impacts from photovoltaic conversion were assessed for the case of large utility plants located in the Southwest U.S. deserts. Decentralized use of photovoltaics on building roofs (very unlikely to any significant extent in the forseeable future) would presumab1y produce impacts similar to those for heating and cooling of buildings. Industrial process heat and tota1-energy systems should even more closely resemble heating and cooling of buildings. No separate table was provided for process heat.

Indirect effects due to materials usage have not been included in the tables. Most conversion schemes use large amounts of materials. Impacts should be similar for all schemes considered here except for bioconversion and possibly ocean thermal conversion. Another problem common to a11 technologies (not just solar energy) which has been omitted is decommissioning of facilities. Transmission lines are common to all centralized electricity generation, and were not mentioned except for the case of wind energy conversion, where the possibility of very wide geographic distribution could present special problems. 
SOLAR THERMAL ELECTRIC CONVERSION

\begin{tabular}{|c|c|c|c|c|c|}
\hline \multicolumn{2}{|c|}{ environmental impact } & $\begin{array}{l}\text { uncertainty } \\
\text { of outcome }\end{array}$ & $\begin{array}{l}\text { need for } \\
\text { concern }\end{array}$ & reason for concern & $\begin{array}{l}\text { possibility } \\
\text { of mitigation }\end{array}$ \\
\hline \multicolumn{2}{|c|}{1 and use } & low & high & $\begin{array}{l}\text { uses } \sim 30 \mathrm{~km}^{2} / \mathrm{GW}_{\mathrm{e}} \\
\text { baseload }\end{array}$ & $20-1,-8-0$ \\
\hline \multicolumn{2}{|c|}{$\begin{array}{l}\text { water use (power plant, } \\
\text { increased population) }\end{array}$} & high & high & $\begin{array}{l}\text { increased demand in } \\
\text { water-deficient regions }\end{array}$ & $\begin{array}{l}\text { moderate (dry cooling } \\
\text { towers, Brayton cycle) }\end{array}$ \\
\hline \multirow{3}{*}{$\begin{array}{l}\text { habitat } \\
\text { destruction }\end{array}$} & construction & high & high & \multirow{3}{*}{$\begin{array}{l}\text { destruction of flora } \\
\text { and fauna and their } \\
\text { habitat }\end{array}$} & \multirow{3}{*}{$\begin{array}{l}\text { moderate (proper } \\
\text { location and design; } \\
\text { care in construction }\end{array}$} \\
\hline & norma1 operation & low & low & & \\
\hline & accidents & moderate & low & & \\
\hline \multirow{3}{*}{ pollution } & construction & moderate & moderate & $\begin{array}{l}\text { surface disruption with } \\
\text { large potential for air, } \\
\text { water pollution }\end{array}$ & $\begin{array}{l}\text { moderate (facility } \\
\text { location, proper } \\
\text { construction methods) }\end{array}$ \\
\hline & operation & moderate & moderate & $\begin{array}{l}\text { mirror cleaning } \\
\text { chemicals }\end{array}$ & $\begin{array}{l}\text { choice of chemistry, } \\
\text { frequency of use }\end{array}$ \\
\hline & accidents & moderate & moderate & $\begin{array}{l}\text { release of storage, } \\
\text { working media }\end{array}$ & $\begin{array}{l}\text { large (choice of } \\
\text { media, proper design) }\end{array}$ \\
\hline \multicolumn{2}{|c|}{$\begin{array}{l}\text { changes in hydrological } \\
\text { cycle }\end{array}$} & high & high & $\begin{array}{l}\text { water runoff, changes in } \\
\text { soil water retention }\end{array}$ & uncertain \\
\hline \multicolumn{2}{|c|}{ increased erosion } & moderate & high & $\begin{array}{l}\text { affects soil quality, } \\
\text { hydrological cycle, } \\
\text { air quality }\end{array}$ & $\begin{array}{l}\text { difficult (proper } \\
\text { design) }\end{array}$ \\
\hline \multicolumn{2}{|c|}{$\begin{array}{l}\text { destruction or disruption } \\
\text { of birds }\end{array}$} & high & low & $\begin{array}{l}\text { injury by beam, } \\
\text { confusion by mirrors }\end{array}$ & $\begin{array}{l}\text { low (location away } \\
\text { from main flyways) }\end{array}$ \\
\hline \multicolumn{2}{|c|}{$\begin{array}{l}\text { environmental disruption } \\
\text { from increased population }\end{array}$} & high & high & $\begin{array}{l}\text { large population influx } \\
\text { in sparsely populated, } \\
\text { delicate regions }\end{array}$ & $\begin{array}{l}\text { low (restrictions } \\
\text { on land use) }\end{array}$ \\
\hline
\end{tabular}


HEATING AND COOLING OF BUILDINGS (WIDESPREAD)

\begin{tabular}{|c|c|c|c|c|}
\hline environmental impact & $\begin{array}{l}\text { uncertainty } \\
\text { of outcome }\end{array}$ & $\begin{array}{l}\text { need } \\
\text { for concern }\end{array}$ & reason for concern & $\begin{array}{l}\text { possibility of } \\
\text { mitigation }\end{array}$ \\
\hline fewer trees may be tolerable & low & $\begin{array}{l}\text { low to } \\
\text { moderate }\end{array}$ & shading of collectors & low \\
\hline $\begin{array}{c}\text { habitat destruction through } \\
\text { urban sprawl }\end{array}$ & low & moderate & $\begin{array}{l}\text { favors low-density, } \\
\text { low-rise housing }\end{array}$ & $\begin{array}{l}\text { low (proper design } \\
\text { of housing) }\end{array}$ \\
\hline $\begin{array}{c}\text { chemical release to } \\
\text { environment }\end{array}$ & high & $\begin{array}{l}\text { high to } \\
\text { moderate }\end{array}$ & $\begin{array}{l}\text { leaks, routine main- } \\
\text { tenance, accidents, } \\
\text { decommissioning }\end{array}$ & $\begin{array}{c}\text { large (proper design, } \\
\text { including choice of } \\
\text { chemicals) }\end{array}$ \\
\hline $\begin{array}{l}\text { glare nuisance to } \\
\text { humans and animals }\end{array}$ & moderate & $\begin{array}{l}\text { Low to } \\
\text { moderate }\end{array}$ & $\begin{array}{l}\text { reflection from glass } \\
\text { collector covers }\end{array}$ & low (orientation) \\
\hline
\end{tabular}


PHOTOVOLTAICS

\begin{tabular}{|c|c|c|c|c|c|}
\hline \multicolumn{2}{|c|}{ environmental impact } & $\begin{array}{l}\text { uncertainty } \\
\text { of outcome }\end{array}$ & $\begin{array}{l}\text { need } \\
\text { for concern }\end{array}$ & reason for concern & $\begin{array}{l}\text { possibility } \\
\text { of mitigation }\end{array}$ \\
\hline \multicolumn{2}{|c|}{ land use } & low & high & $\begin{array}{c}\text { uses } \sim 60 \mathrm{~km}^{2} / \mathrm{GW}_{\mathrm{e}} \\
\text { baseload }\end{array}$ & none \\
\hline \multicolumn{2}{|c|}{ water use } & high & high & $\begin{array}{l}\text { increased demand in } \\
\text { water-deficient regions, } \\
\text { especially if cells } \\
\text { must be cooled }\end{array}$ & moderate (air cooling \\
\hline \multirow{3}{*}{ pollution } & construction & moderate & high & $\begin{array}{l}\text { surface disruption with } \\
\text { large potential for } \\
\text { air, water pollution }\end{array}$ & $\begin{array}{l}\text { moderate (facility } \\
\text { location, proper } \\
\text { construction methods) }\end{array}$ \\
\hline & normal operation & Low & low & $\begin{array}{l}\text { release of cleaning } \\
\text { fluid, cell materials } \\
\text { by corrosion \& erosion }\end{array}$ & $\begin{array}{l}\text { moderate (choice of } \\
\text { fluid, cell materials } \\
\text { design }\end{array}$ \\
\hline & accidents & high & moderate & $\begin{array}{l}\text { Release of combustion } \\
\therefore \quad \text { products }\end{array}$ & $\begin{array}{l}\text { moderate (choice of } \\
\text { cel1 materials) }\end{array}$ \\
\hline \multicolumn{2}{|c|}{ habitat destruction } & \multirow{4}{*}{\multicolumn{4}{|c|}{ \} substantially the same as solar thermal case }} \\
\hline changes & $\begin{array}{l}\text { le } \\
\text { le }\end{array}$ & & & & \\
\hline \multicolumn{2}{|c|}{ increased erosion } & & & & \\
\hline $\begin{array}{l}\text { environ } \\
\text { from } i\end{array}$ & $\begin{array}{l}1 \text { disruption } \\
\text { sed population }\end{array}$ & & & & \\
\hline
\end{tabular}


OCEAN THERMAL CONVERSION

\begin{tabular}{|c|c|c|c|c|}
\hline environmentai impact & $\begin{array}{l}\text { uncertainty } \\
\text { of outcome }\end{array}$ & $\begin{array}{l}\text { need } \\
\text { for concern }\end{array}$ & reason for concern & $\begin{array}{l}\text { possibility } \\
\text { of mitigation }\end{array}$ \\
\hline land use & low & low & $\begin{array}{l}\text { on-shore support } \\
\text { facilities }\end{array}$ & moderate(location) \\
\hline $\mathrm{CO}_{2}$ release & high & moderate & $\begin{array}{l}\text { effect on climate. } \sim \frac{1}{3} \\
\text { release rate of fossil } \\
\text { plants. (Ref. } 22)\end{array}$ & uncertain \\
\hline $\begin{array}{c}\text { change local' surface species } \\
\text { composition and abundance }\end{array}$ & high & high. & $\begin{array}{l}\text { upwelling nutrients, } \\
\text { disrupting flow and } \\
\text { thermal patterns }\end{array}$ & $\operatorname{lov}($ design $)$ \\
\hline $\begin{array}{l}\text { entrainment of } \\
\text { marine organisms }\end{array}$ & low & moderate & $\begin{array}{l}\text { cold water intake, hot } \\
\text { water heat exchanger }\end{array}$ & moderate (design) \\
\hline release of toxic chemicals & high & moderate & $\begin{array}{c}\text { biocides to prevent } \\
\text { biofouling, accidental } \\
\text { release of working } \\
\text { fluids }\end{array}$ & $\begin{array}{l}\text { moderate (design and } \\
\text { operation procedures) }\end{array}$ \\
\hline $\begin{array}{c}\text { impact on down-current } \\
\text { ecosystems }\end{array}$ & high & moderate & $\begin{array}{l}\text { changed surface tem- } \\
\text { perature and current } \\
\text { patterns if many power } \\
\text { plants are built in } \\
\text { one region }\end{array}$ & Iow (siting of plan \\
\hline $\begin{array}{l}\text { oil spills and } \\
\text { chemical releases }\end{array}$ & moderate & high & $\begin{array}{l}\text { ship collisions with } \\
\text { power plants }\end{array}$ & $\begin{array}{l}\text { moderate (navigation } \\
\text { aids, ship lanes) }\end{array}$ \\
\hline $\begin{array}{l}\text { Pollution of waste products } \\
\text { from energy intensive } \\
\text { materials production }\end{array}$ & high & moderate & $\begin{array}{l}\text { Pollution of marine } \\
\text { environment }\end{array}$ & high (1and disposa1) \\
\hline
\end{tabular}


WIND (MULTIMEGAWATT SCALE)

\begin{tabular}{|c|c|c|c|c|}
\hline environmental impact & $\begin{array}{l}\text { uncertainty } \\
\text { of outcome }\end{array}$ & $\begin{array}{l}\text { need } \\
\text { for concern }\end{array}$ & reason for concern & $\begin{array}{l}\text { possibility } \\
\text { of mitigation }\end{array}$ \\
\hline land use (area of array) & low & high & $\sim 35-150 \mathrm{~km}^{2} / \mathrm{GW}_{\mathrm{e}}$ & $\begin{array}{l}\text { moderate design and } \\
\text { choice of spacing) }\end{array}$ \\
\hline avian destruction & high & $\begin{array}{l}\text { low to } \\
\text { moderate }\end{array}$ & $\begin{array}{l}\text { could threaten rare } \\
\text { or endangered species }\end{array}$ & turbine siting \\
\hline $\begin{array}{l}\text { disruption of wildlife and } \\
\text { domestic animals during } \\
\text { operation }\end{array}$ & high & moderate & $\begin{array}{l}\text { noise, local wind } \\
\text { patterns, pressure } \\
\text { waves, physical } \\
\text { presence }\end{array}$ & low (design) \\
\hline $\begin{array}{l}\text { habitat destruction } \\
\text { during construction. }\end{array}$ & low & moderate & $\begin{array}{l}\text { roads, off-road } \\
\text { equipment, erosion }\end{array}$ & $\begin{array}{l}\text { moderate (care and } \\
\text { proper technique) }\end{array}$ \\
\hline $\begin{array}{l}\text { habitat destruction for } \\
\text { transmission lines } \\
\text { and storage }\end{array}$ & high & moderate & $\begin{array}{l}\text { pumped storage, chem- } \\
\text { ical storage, } \\
\text { transmission lines }\end{array}$ & moderate (design) \\
\hline Aesthetic considerations & high & high & $\begin{array}{l}\text { highly visible ridge } \\
\text { tops or open panoramas } \\
\text { are likely sites }\end{array}$ & $\begin{array}{l}\text { low-design and } \\
\text { location }\end{array}$ \\
\hline
\end{tabular}


BIOCONVERSION - ENERGY PLANTATIONS

\begin{tabular}{|c|c|c|c|c|}
\hline environmental impact & $\begin{array}{l}\text { uncertainty } \\
\text { of outcome }\end{array}$ & $\begin{array}{l}\text { need } \\
\text { for concern }\end{array}$ & reason for concern & $\begin{array}{l}\text { possibility } \\
\text { of mitigation }\end{array}$ \\
\hline Iand use & $\begin{array}{l}\text { low to } \\
\text { moderate }\end{array}$ & high & $\begin{array}{l}\text { displaces natural pop- } \\
\text { ulations; competes with } \\
\text { farmland and forest } \\
\text { products. Perhaps } 500- \\
2000 \mathrm{~km}^{2} / \mathrm{GW}_{\mathrm{e}} .\end{array}$ & $\begin{array}{l}\text { none (must choose } \\
\text { between energy plantations } \\
\text { and either wild lands or } \\
\text { traditional agricultural } \\
\text { lands) }\end{array}$ \\
\hline $\begin{array}{l}\text { air pollution } \\
\text { at plantation }\end{array}$ & moderate & high & $\begin{array}{l}\text { dust, pesticides, } \\
\text { recycled ash }\end{array}$ & $\begin{array}{c}\text { moderate (proper } \\
\text { technology and } \\
\text { procedures) }\end{array}$ \\
\hline water use & moderate & high & $\begin{array}{l}\text { probable need for } \\
\text { irrigation }\end{array}$ & $\begin{array}{c}\text { moderate (crop } \\
\text { selection, location,) }\end{array}$ \\
\hline water pollution & $\begin{array}{l}\text { low to } \\
\text { moderate }\end{array}$ & high & $\begin{array}{l}\text { fertilizer and pesti- } \\
\text { cide runoff, erosien }\end{array}$ & $\operatorname{smal1}$ \\
\hline soil quality degradation & moderate & high & $\begin{array}{l}\text { removal of organic } \\
\text { matter, erosion }\end{array}$ & uncertain \\
\hline $\begin{array}{l}\text { local reduction of some } \\
\text { species }\end{array}$ & moderate & high & $\begin{array}{l}\text { ecosystem simplifica- } \\
\text { tion, destruction of } \\
\text { desirable } \\
\text { species by pesticides } \\
\text { and herbicides }\end{array}$ & $\begin{array}{l}\text { low to moderate } \\
\text { (type of crop, loca- } \\
\text { tion, farming } \\
\text { practices) }\end{array}$ \\
\hline
\end{tabular}


BIOCONVERSION - ENERGY PLANTATIONS (con't)

\begin{tabular}{|c|c|c|c|c|}
\hline environmental impact & $\begin{array}{l}\text { uncertainty } \\
\text { of outcome }\end{array}$ & $\begin{array}{l}\text { need } \\
\text { for concern }\end{array}$ & reason for concern & $\begin{array}{l}\text { possibility } \\
\text { of mitigation }\end{array}$ \\
\hline $\begin{array}{c}\text { Regional } \\
\text { changes in indigenous } \\
\text { species }\end{array}$ & high & low & $\begin{array}{l}\text { meteorological and } \\
\text { food chain modification }\end{array}$ & uncertain \\
\hline
\end{tabular}


BIOCONVERSION - WASTE UTILIZATION AND CONVERSTON PROCESSES

\begin{tabular}{|c|c|c|c|c|}
\hline environmental impact & $\begin{array}{l}\text { uncertainty } \\
\text { of outcome }\end{array}$ & $\begin{array}{l}\text { need } \\
\text { for concern }\end{array}$ & reason for concern & $\begin{array}{l}\text { possibility } \\
\text { of mitigation }\end{array}$ \\
\hline air pollution & high & high & $\begin{array}{c}\text { combustion products, } \\
\text { emissions from } \\
\text { conversion process }\end{array}$ & $\begin{array}{c}\text { moderate (proper } \\
\text { technology) }\end{array}$ \\
\hline water use & high & high & $\begin{array}{c}\text { fermentation and } \\
\text { gasification use } \\
\text { water }\end{array}$ & $\begin{array}{l}\text { high (choice of } \\
\text { technology, proper } \\
\text { design) }\end{array}$ \\
\hline water pollution & high & high & $\begin{array}{l}\text { disposal of residuals } \\
\text { and fate of effluents }\end{array}$ & $\begin{array}{c}\text { moderate (process } \\
\text { design and } \\
\text { disposal techniques) }\end{array}$ \\
\hline land use & moderate & $\begin{array}{l}\text { low to } \\
\text { moderate }\end{array}$ & $\begin{array}{c}\text { land for collection, } \\
\text { storage, treatment }\end{array}$ & $\begin{array}{l}\text { low (facility } \\
\text { siting) }\end{array}$ \\
\hline solid wastes & $\begin{array}{l}\text { low to } \\
\text { moderate }\end{array}$ & moderate & $\begin{array}{c}\text { varies with process: } \\
\text { ash, sludge, etc. } \\
\text { disposal problem }\end{array}$ & $\begin{array}{c}\text { moderate (disposal } \\
\text { techniques) }\end{array}$ \\
\hline toxic materials & high & high & $\begin{array}{l}\text { metals and chemicals } \\
\text { from municipal and } \\
\text { industrial wastes, } \\
\text { pathogens from muni- } \\
\text { cipal and animal } \\
\text { wastes }\end{array}$ & $\begin{array}{l}\text { moderate (process } \\
\text { design, disposal } \\
\text { techniques) }\end{array}$ \\
\hline soil quality degradation & moderate & high & $\begin{array}{c}\text { removal of organic } \\
\text { material }\end{array}$ & uncertain \\
\hline
\end{tabular}


REFERENCES

1. Bockris, J. O'M. Energy: The Solar-Hydrogen Alternative, John Wiley \& Sons, New York, 1975.

2. Selcuk, M. K., Survey of Several Central Reveiver Solar Thermal Power Plant Design Concepts, Jet Propulsion Laboratory, \#EM 342-311, Pasadena, California, August 1975.

3. Solar Energy for Earth, An AIAA Assessment, American Institute of Aeronautics and Astronautics, Ed. by H. J. Killian, et al., April 1975.

4. Solar Thermal Conversion Mission Analysis, 5 vo1., The Aerospace Corporation, 1974.

5. Dynamic Conversion of Solar Generated Heat to Electricity, Honeywe11 Inc., NASA CR-134724.

6. Loferski, J. J., The Principles of Photovoltaic Solar Energy Conversion, Brown University, Rhode Island, March 1972.

7. Direct Energy Conversion, Ed. by G. W. Sutton, McGraw-Hi11, New York, 1966.

8. Solar Sea Thermal Energy, Ninety-Third Congress, second session, Congressional Committee print No. 41, Committee on Science and Astronautics (1974) .

9. Putnam, P. C., Power from the Wind, Van Nostrand Reinhold Co., New York, 1948.

10. Duffie, J. A., and Beckman, W. A., Solar Energy Thermal Processes, Interscience, New York, 1974.

11. Kreider, J. F., and Kreith, T., Solar Heating and Cooling, McGraw-Hi11, New York, 1975.

12. Reese, E. T., et al., "Cellulose as a Nove1 Energy Source," in Advances in Biochemical Engineering, Vol. 2, Springer-Verlag, New York, 1972.

13. Benneman, J. R., Hydrogen Production from Water and Sun1ight by Photosynthetic Process, University of California, San Diego, La Jolla, Califormia, December 1973.

14. Stebbins, Robert C., "Off-Road Vehicles and the Fragile Desrt," The American Biology Teacher, Vol. 36, No. 4, April 1974.

15. Wilshire, H. G. and Nakata, J. K., "Off-Road Vehicle Effects on California's Mojave Desert," California Geology, California Division of Mines and Geology, Sacramento, June 1976.

16. Deserts of the World, Ed. by G. W. McGinnies et a1., The University of Arizona Press, Tucson, 1968.

17. Cooke, R. U., Geomorphology in Deserts, University of Califormia Press, Berkeley, 1973. 
18. Fuller, W. H., "Desert Soils," Ch. 2 in Desert Biology, Vo1. II, Ed. by G. W. Brown, Jr., Academic Press, New York, 1974.

19. Davis, S. N., "Hydrogeology of Arid Regions," Chapter I in Desert Biology, Vol. II, Ed. by G. W. Brown, Jr., Academic Press, New York, 1974.

20. Von Hipple, F. and Williams, R. H., "Solar Technologies," in Bulletin of the Atomic Scientists, November 1975.

21. Tait, R. V. and De Santo, R. S. Elements of Marine Ecology, Springer-Verlag, New York, 1975.

22. Danyluk, S. A., Argonne National Laboratory, unpublished report.

23. (Calef, 1976)

24. Stern, A. C., Editor, Air Pollution, Vo1. III, Academic Press, New York, 1968 .

25. Environmental Quality, Council on Environmental Quality, U. S. Gov't. Printing Office, Stock No. 4000-00327, Washington, Dec. 1975.

26. Consumptive Water Use Implications of the Proposed EPA Effluent Guidelines for Steam-Electric Power Generation, Espey, Huston and Associates, Austin, Texas, May 31, 1974. 
